\title{
Determination of Centromere Number of Chromosomes Involved in Robertsonian Translocation by using Fluorescence in Situ Hybridization (FISH)
}

Tulin Cora ${ }^{1}$, Hasan Acar ${ }^{1}$, Yusuf Özkul ${ }^{2}$

${ }^{1}$ Selcuk University, Selcuklu Medical School, Department of Medical Genetics, Konya

${ }^{2}$ Erciyes University, Medical School, Department of Medical Genetics, Kayseri

Eur J Basic Med Sci 2012;2 (1):1-5

Geliș Tarihi (Received): 03-11-2011

Kabul Tarihi (Accepted): 11-11-2011

Correspondence (Yazıșma Adresi):

Tulin CORA, PhD

Selcuk University, Selcuklu Medical Faculty Medical Genetic Department

Selcuklu Konya

email:tulincora@gmail.com

\section{ABSTRACT}

Robertsonian translocation is one of the major chromosomal re-arrangements and constitutes $18 \%$ of all genetic abnormalities with an incidence of $1 / 1000$ in the general population. Robertsonian translocations are characterized centric fusion of the long arms of the acrocentric chromosomes and generally occur between chromosome 13q,14q and 14q,21q. In this study, the centromere numbers of 22 patients with Robertsonian translocations were evaluated by using fluorescence in situ hybridization with repetitive DNA probes localized on the centromeric region of acrocentric chromosomes. We detected that all Robertsonian translocation have a single cetromere. However some of case showed a distinct size of FISH signals on cetromere region, which may indicate the duplication or two different satellite DNA sequences. Therefore these cases should be clarified for the composition of monocenric centromere sequence.

Key Words: Robertsonian translocation, centromere, dicentric chromosome, FISH

Robertsonian Translokasyonlarda ișe Karıșan Kromozomların Sentromer Sayısının Floresan in Situ Hibridizasyon (FISH) ile Belirlenmesi

\section{ÖZET}

Robertsonian translokasyon major kromozomal yeniden düzenlenmelerden biridir. Bu anomali genel populasyonda 1/1000 sıklık ile tüm genetik anomalilerin \% 18'ini olușturur. Robertsonian translokasyonlar, akrosentrik kromozomların uzun kollarının füzyonu ile karekterize ve genellikle kromozom $13 q$ ve $14 q, 14 q$ ve $21 q$ arasında meydana gelmektedir. Mevcut çalıșmada 4 farklı tipde 22 Robertsonian translokasyon taşıyıcı ve hasta bireyin, akrosentrik kromozomlarındaki sentromer sayıları bu bölgelere spesifik repetetif DNA probları ile fulorescence in situ hybridization tekniği kullanılarak incelendi. Elde edilen FISH sonuçlarına göre Robertsonian translokasyonların tümünün monosentrik olduğu tesbit edildi. Bununla birlikte vakaların bazılarının setromer bölgesinde farklı büyüklükte FISH sinyalleri gözlendi. Bu farklı yapının sebebi sentromeri olușturan dizilerin duplikasyonu veya iki farklı satellit DNA sekansı olabilir. Sonuç olarak, çalıșmaya dahil olan tüm vakalar monosentrik olmakla birlikte, monosentrik yapıyı oluşturan satellit DNA dizilerinin karekterize edilmesi gerekmektedir.

Anahtar Kelimeler: Robertsonian translokasyonlar, sentromer, disentrik kromozom, FISH 


\section{INTRODUCTION}

Robertsonian translocations are one of the most common structural chromosomal aberrations observed in humans and occur in approximately 1 in every 1000 newborns (1). This translocation can be either de novo or be transmitted by one of carrier parent. Robertsonian translocations are characterized centric fusion of the long arms of the acrocentric chromosomes 13, 14, 15, 21 and 22, with the translocated chromosome bearing either one or two centromeres and resulting in a 45 or 46 chromosome karyotype. The majority of Robertsonian translocations involve two nonhomologous acrocentric chromosomes. The most frequent Robertsonian translocations are der $\mathrm{t}(13 \mathrm{q} ; 14 \mathrm{q})$ and $t(14 q ; 21 q)$ have an estimated frequency of 0.97 and 0.20 , respectively (2). The acrocentric chromosomes in man have been intensively investigated, both because of their frequent involvement in chromosomal aberrations and aneuploidy and because of their unique structural properties (3). Rearrangements of the acrocentric chromosomes are associated with an increased risk of aneuploidy. In generally, carriers of Robertsonian translocations are phenotypically normal but are at increased risk for infertility, spontaneous abortions or chromosomally unbalanced offspring. Malsegregation of Robertsonian translocation, results in trisomy or monosomy of complete chromosomes (4).

The centromere regions are mystery for different scientists; for cytologists, it is the primary constriction of the mitotic chromosome, for geneticists it is the origin from which recombination distances are measured. Other equally valid definitions include the following: a specialized DNA sequence, a specialized type of heterochromatin, a structure that regulates sister-chromatid-pairing, a structure that attaches the chromosome to the ends of growing or shrinking microtubules, a marshalling region where chromosomal passenger proteins congregate prior to their function elsewhere during the closing stages of mitosis, and a signaling device that monitors chromosomal alignment and tells the cell when it is safe to segregate sister chromatids in mitosis and homologs in meiosis (5). Molecular studies have shown that the pericentromeric and short-arm regions of acrocentric chromosomes have extensive sequence homology, although some sequences are not common to all of the acrocentrics. Several distinct and tandemly repetitive sequences are localized to these regions. Alpha-satellite DNA sequence is a major class of repetitive DNA found at the centromeric region of each human chromosome (6). Centromers can be involved in chromosomal anomalies. One of those is Robertsonian translocations. Robertsonian translocations have either single or two centromeres. Therefore we aimed to evaluate the centromer numbers in the patients having Robertsonian translocation by using fluorescence in-situ hybridization (FISH) techniques with acrocentric centromere-specific probes.

\section{MATERIAL AND METHODS}

\section{Patients}

This study includes total 22 unrelated (13 female and 9 male) patients with Robertsonian translocation. Twelve of them were Robertsonian translocation carriers including $3 \mathrm{t}(14 ; 21)$ and $9 \mathrm{t}(13 ; 14)$ who have repeated miscarriages and infertility history. The other 10 patients were Down syndrome. Five of them were $t(14 ; 21), 3 t(21 ; 21)$ and $2 t(15 ; 21)$. The age of the patients ranged from one mounth to 28 years.

\section{Fluorescence in Situ Hybridization (FISH)}

In this study, patients consulting for different purposes such infertility, repeated miscarriages, and birth of a malformed child were included. Conventional cytogenetic analysis in lymphocyte chromosomes revealed a chromosomal translocation for each patient. Briefly, standard chromosome preparations from blood lymphocytes of the carrier and the control groups were used. In order to verify the number of centromere on Robertsonian translocation, FISH analyses were done by using D13Z1/D21Z1 and D14Z1/D22Z1 and D15Z1 probes (Cambio, UK). D13Z1/D21Z1 was labeled with Cy3 (fluoresces red), and D14Z1/D22Z1 was labeled with biotin and then was detected with avidin conjugated with fluorescein isothiocyanate (FITC; fluoresces green) according to previously published procedures (7). For the samples, the probe mixtures were denatured at $70^{\circ} \mathrm{C}$ for $10 \mathrm{~min}$, while DNA was denatured in $70 \%$ formamide $/ 2$ SSC at $70^{\circ} \mathrm{C}$ for $2-3 \mathrm{~min}$. The slides were then dehydrated through an ascending alcohol series (70, 85 , and $100 \%$, and airdried. The denatured probe mixture was applied onto the slides. The hybridization was performed in $40^{\circ} \mathrm{C}$ moisture chamber overnight. The slides were washed twice for 5 min with 2 SSC, 50\% formamide $/ 2 \times S S C$ and $2 \times S S C$ at $42{ }^{\circ} \mathrm{C}$. They were then stained with a counterstain medium containing DAPI (40,6-diamidino-2-phenyl-indole). 
Table 1. Karyotypes, circumstances of discovery of structural chromosomal abnormality and centromer constitution used to perform FISH of 22 patient or carriers of Robertsonian translocation.

\begin{tabular}{|c|c|c|c|c|}
\hline Patient & Karyotype & Discovery & FISH probe & Centromer constitution \\
\hline 1 & $46, X X, t(21 ; 21)$ & Down Sendromu & D13Z1/D21Z1 & Monocentric \\
\hline 2 & $46, X X, t(21 ; 21)$ & Down Sendromu & D13Z1/D21Z1 & Monocentric \\
\hline 3 & $46, X X, t(21 ; 21)$ & Down Sendromu & D13Z1/D21Z1 & Monocentric \\
\hline 4 & $46, X Y, t(14 ; 21)$ & Down Sendromu & D13Z1/D21Z1andD14Z1/ D22Z1 & Monocentric \\
\hline 5 & $46, X X, t(14 ; 21)$ & Down Sendromu & D13Z1/D21Z1andD14Z1/ D22Z1 & Monocentric \\
\hline 6 & $46, X X, t(14 ; 21)$ & Down Sendromu & D13Z1/D21Z1andD14Z1/ D22Z1 & Monocentric \\
\hline 7 & $46, X Y, t(14 ; 21)$ & Down Sendromu & D13Z1/D21Z1andD14Z1/ D22Z1 & Monocentric \\
\hline 8 & $46, X Y, t(14 ; 21)$ & Down Sendromu & D13Z1/D21Z1andD14Z1/ D22Z1 & Monocentric \\
\hline 9 & $46, X Y, t(15 ; 21)$ & Down Sendromu & D13Z1/D21Z1 and D15Z1 & Monocentric \\
\hline 10 & $46, X Y, t(15 ; 21)$ & Down Sendromu & D13Z1/D21Z1 and D15Z1 & Monocentric \\
\hline 11 & $45, X X, t(14 ; 21)$ & Repeated miscarriages & D13Z1/D21Z1andD14Z1/ D22Z1 & Monocentric \\
\hline 12 & $45, X X, t(14 ; 21)$ & Repeated miscarriages & D13Z1/D21Z1andD14Z1/ D22Z1 & Monocentric \\
\hline 13 & $45, X Y, t(14 ; 21)$ & Repeated miscarriages & D13Z1/D21Z1andD14Z1/ D22Z1 & Monocentric \\
\hline 14 & $45, X X, t(13 ; 14)$ & Repeated miscarriages & D13Z1/D21Z1andD14Z1/ D22Z1 & Monocentric \\
\hline 15 & $45, X X, t(13 ; 14)$ & Repeated miscarriages & D13Z1/D21Z1andD14Z1/ D22Z1 & Monocentric \\
\hline 16 & $45, X X, t(13 ; 14)$ & Repeated miscarriages & D13Z1/D21Z1andD14Z1/ D22Z1 & Monocentric \\
\hline 17 & $45, \mathrm{XX}, \mathrm{t}(13 ; 14)$ & Repeated miscarriages & D13Z1/D21Z1andD14Z1/ D22Z1 & Monocentric \\
\hline 18 & $45, X X, t(13 ; 14)$ & Repeated miscarriages & D13Z1/D21Z1andD14Z1/ D22Z1 & Monocentric \\
\hline 19 & $45, X Y, t(13 ; 14)$ & Primary infertility & D13Z1/D21Z1andD14Z1/ D22Z1 & Monocentric \\
\hline 20 & $45, \mathrm{XY}, \mathrm{t}(13 ; 14)$ & $\begin{array}{l}\text { Oligoasthenoteratozoo- } \\
\text { spermia }\end{array}$ & D13Z1/D21Z1andD14Z1/ D22Z1 & Monocentric \\
\hline 21 & $45, X Y, t(13 ; 14)$ & $\begin{array}{l}\text { Oligoasthenoteratozoo- } \\
\text { spermia }\end{array}$ & D13Z1/D21Z1andD14Z1/ D22Z1 & Monocentric \\
\hline 22 & $45, X Y, t(13 ; 14)$ & $\begin{array}{l}\text { Oligoasthenoteratozoo- } \\
\text { spermia }\end{array}$ & D13Z1/D21Z1andD14Z1/ D22Z1 & Monocentric \\
\hline
\end{tabular}

The slides were examined with an epifluorescence microscope (Nikon, Optiphot) equipped with a set DAPI, fluorescein isothiocyanate (FITC) and rhodamine filters. These filters allow individual detection of red and green.

\section{RESULTS}

In this study, we analysed centromeric number in 22 unrelated (13 female and 9 male) Robertsonian translocation patients using FISH technique. FISH analysis on metaphase and interphase cells from the patient's lymphocyte using probes to the centromeres of chromosomes 13/21, 14/22 and 15 revealed that the translocation had a hybridization signal from each probe, indicating that these rearrangements are monocentric. The results obtained from both conventional cytogenetic and FISH analaysis with chromosome spesific probes are given in Table 1. FISH signals on some translocations chromosomes were appeared as in distinc size. 


\section{DISCUSSION}

The centromere is an essential functional domain responsible for the correct inheritance of eukaryotic chromosomes during cell division. Molecular studies have shown that the pericentromeric and short-arm regions of these five pairs of acrocentric chromosomes have extensive sequence homology, although some sequences are not common to all of the acrocentrics. Several distinct and tandemly repetitive sequences are localized to these regions. Alpha-satellite is a major class of repetitive DNA found at the centromeric region of each human chromosome (6). Acrocentric chromosomes contain a number of satellite subfamilies, some of which are shared by different acrocentrics. These shared sequences have been postulated to be involved in the formation of Robertsonian translocations and in nonrandom participation of chromosomes 13, 14, and 21 in most Robertsonian translocations (1).

The short arms of acrocentric chromosomes can be divided into three distinct portions. The proximal short arm (pll) contains satellites I-IV $(8,9)$, beta-satellite (10) and the interspersed 724 repeated sequence (11). The stalk, or nucleolus organizer region (NOR) (p12), contains the $18 \mathrm{~S}$ and $28 \mathrm{~S}$ ribosomal genes (12). Finally, beta-satellite DNA and 724 DNA have been mapped to the distal cytological satellite (p13). In Robertsonian translocation, single or double centromeres may be formed depending on the breakpoint of chromosomal regions. These centromeric composition and centromer number have an effect on chromosomal segregation, resulting in the further abnormalities.

In the present study, we analysed centromeric number in 22 unrelated (13 female and 9 male) Robertsonian translocation patients or carriers who have four different type of this by using FISH technique. It has been determined that centromeric number is structurally monocentric in all of Robertsonian translocations. FISH analysis on metaphase cells from the patient's lymphocyte culture using probes to the centromeres of chromosomes 13, 14, 15, 21 and 22 revealed that Robertsonian translocations had a hybridization signal from each probe, indicating that this rearrangements is monocentric. However the structure at the centromere of the rearrangements could not be distinquish the origine of centromeric composition in single color FISH study.

In the literature, Lemyre $\mathrm{E}$, et al (13) suggested that most Robertsonian translocations are dicentric and also the location of chromosomal breaks leading to their formation occur in the acrocentric short arm. Furthermore, number of authors also confirm that in situ hybridization methods were used to clarify that the majority of Robertsonian translocations retain the alpha satellite DNA from both chromosomes involved and thus are structurally dicentric, with the breakpoints usually located in the acrocentric short arms, proximal to the NOR $(3,7,9,14,15,16)$. These kind of dicentric chromosomes are stable during the cell division due to one of centromer inactivation (17). However, this translocation may result in unbalanced ofspring in the next generation.

In our present study, some of case showed a distinct size of FISH signals, which may indicate the duplication or two different satellite DNA sequences in adjacent status. Therefore, these cases should be clarified for the satellite DNA composition of monocenric centromere sequence by using multicolor FISH study. These sequence composition may effect on the occurence of interchromosomal effect raising chromosome aneuploidy and/or the behavior of translocated chromosome segregation in next generation.

This study was supported by a Selcuk University, Research Foundation.

\section{REFERENCES}

1. Therman E, Susman B, Denniston C. The nonrandom participation of human acrocentric chromosomes in Robertsonian translocations. Ann Hum Genet 1989;53: 49-65.

2. Frydman N, Romana S, Le Lorc'h M, Vekemans M, Frydman $R$, Tachdjian G. Assisting reproduction of infertile men carrying a Robertsonian translocation. Hum Reprod 2001;16: 2274-7.

3. Han J-Y, Choo KHA, Shaffer LG. Molecular cytogenetic characterization of 17 rob(13ql4q) Robertsonian translocations by FISH, narrowing the region containing the breakpoints. Am J Hum Genet 1994;55: 960-7.

4. Pellestor F. Analysis of meiotic segregation in a man heterozygous for a 13;15 Robertsonian translocation and a review of the literature. Hum Genet 1990;85(1):49-54.

5. Craig J.M, Earnshaw W. C, and Vagnarelli P. Mammalian Centromeres: DNA Sequence, Protein Composition, and Role in Cell Cycle Progression Experimental Cell Research 1999;246: 249-62.

6. Choo K.H. Vissel B, Nagy A, Earle E, Kalitsis P Nucleic Acids Res. 1991;19, 1179-82. 
7. Page SL, Shin JC, Han JY, Choo KH, Shaffer LG. Breakpoint diversity distinct mechanisssms for Robertsonian translocation formation. Hum Mol Genet 1996;5(9):1279-88.

8. Gosden JR, Lawrie SS, Gosden CM. Satellite DNA sequences in the human acrocentric chromosomes: information from translocations and heteromorphisms. Am J Hum 1981; Genet 33:243-51.

9. Gravholt $\mathrm{CH}$, Friedrich $U$, Caprani M, Jorgensen $A L$. Breakpoints in Robertsonian translocations are localized to satellite III DNA by fluorescence in situ hybridization. Genomics 1992; 14:924-30.

10. Waye JS, Willard HF. Human beta satellite DNA: genomic organization and sequence definition of a class of highly repetitive tandem DNA. Proc Natl Acad Sci U S A 1989;86(16):6250-4.

11. Kurnit DM, Roy S, Stewart GD, Schwedock J, Neve RL, Bruns GA, Van Keuren ML, Patterson D. The 724 family of DNA sequences is interspersed about the pericentromeric regions of human acrocentric chromosomes. Cytogenet Cell Genet 1986;43(1-2):109-16.

12. Worton RG, Sutherland J, Sylvester JE, Willard HF, Bodrug $S$, Dube I, Duff C, Kean V, Ray PN, Schmickel RD. Human ribosomal RNA genes: orientation of the tandem array and conservation of the 5' end. Science 1988; 239:64-8.
13. Lemyre $E$, der Kaloustian VM, Duncan AM. Stable nonRobertsonian dicentric chromosomes: four new cases and a review. J Med Genet 2001;38(1):76-9.

14. Wolff DJ, Schwartz S. Characterization of Robertsonian translocations by using flourescence in situ hybridization. Am J Hum Genet 1992;50(1):174-81.

15. Sullivan BA, Jenkins Ls, Karson EM, Leana-Cox J, Schwartz $S$. Evidence for structural heterogeneity from molecular cytogenetic analysis of dicentric Robertsonian translocation. Am J Hum Genet 1996;59(1):165-75.

16. Page SL, Shaffer LG. Nonhomologous Robertsonian translocations form predominantly during female meiosis. Nature Genet 1997; 15: 231-2.

17. Sullivan BA, Wolff DJ, Schwartz S. Analysis of centromeric activity in Robertsonian translocations: implications for a functional acrocentric hierarchy. Chromosoma 1994;103: 459-67. 